\title{
ß-Spectrin São PauloII, a novel frameshift mutation of the ß-spectrin gene associated with hereditary spherocytosis and instability of the mutant mRNA
}

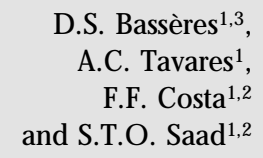

D.S. Bassères ${ }^{1,3}$,

A.C. Tavares ${ }^{1}$,

F.F. Costa ${ }^{1,2}$

and S.T.O. Saad ${ }^{1,2}$

\author{
${ }^{1} \mathrm{Hemocentro}$, and Departamentos de ${ }^{2} \mathrm{Clínica}$ M édica, and \\ ${ }^{3}$ Genética e Evolução, Universidade Estadual de Campinas, \\ Campinas, SP, Brasil
}

\section{Correspondence \\ S.T.O. Saad \\ Hemocentro, UNICAMP \\ Caixa Postal 6198 \\ 13081-970 Campinas, SP \\ Brasil \\ E-mail: sara@ obelix.unicamp.br \\ Presented at the XVII Annual Meeting of the Federação de Sociedades de Biologia Experimental, Salvador, BA, Brazil, August 28-31, 2002.}

Research supported by CNPq and FAPESP.

Received April 5, 2002

Accepted July 10, 2002

\section{Abstract}

Hereditary spherocytosis (HS) is a common inherited anemia characterized by the presence of spherocytic red cells. Defects in several membrane protein genes have been involved in the pathogenesis of HS. B-Spectrin-related HS seems to be common. We report here a new mutation in the $\beta$-spectrin gene coding region in a patient with hereditary spherocytosis. The patient presented acanthocytosis and spectrin deficiency and, at the DNA level, a novel frameshift mutation leading to HS, i.e., a C deletion at codon 1392 (ß-spectrin São Paulo ${ }^{\mathrm{II}}$ ), exon 20. The mRNA encoding $\beta$-spectrin São Paulo ${ }^{\mathrm{II}}$ was very unstable and the mutant protein was not detected in the membrane or in other cellular compartments. It is interesting to note that frameshift mutations of the $\beta$-spectrin gene at the 3 ' end allow the insertion of the mutant protein in the red cell membrane, leading to a defect in the auto-association of the spectrin dimers and consequent elliptocytosis. On the other hand, $\beta$-spectrin São Paulo ${ }^{\text {II }}$ protein was absent in the red cell membrane, leading to spectrin deficiency, HS and the presence of acanthocytes.

Hereditary spherocytosis (HS) is a common inherited anemia characterized by the presence of spherocytic red cells which have increased osmotic fragility (1). This disorder is heterogeneous in terms of its clinical presentation, molecular basis and inheritance (2). Several gene defects have been involved in the pathogenesis of HS. The ankyrin gene is the most frequently involved and few $\beta$ spectrin mutations have been described (39). B-Spectrin mutations are also present in hereditary elliptocytosis. In fact, this protein has several binding sites on the red cell membrane such as the ankyrin, protein 4.1 and spectrin dimer auto-association sites.

We have studied a Brazilian family presenting with HS and spectrin deficiency. The study was approved by the Hospital Ethics Committee and written informed consent was obtained from the participants. The proposita (RS) was a 20-year-old white woman who was diagnosed on the basis of the presence of splenomegaly, jaundice, hemolysis and increased osmotic fragility of the erythrocytes. 
Her peripheral smear displayed many spherocytes and acanthocytes (Figure 1). Her father, two uncles and her brother were also affected, some of them having undergone splenectomy (Figure 1). Her hematological values were: $12.5 \mathrm{~g} / \mathrm{dl}$ hemoglobin, $3.8 \mathrm{x}$ $10^{12} / 1$ red blood cells, $87 \mathrm{fl}$ mean corpuscular volume, $37.7 \mathrm{~g} / \mathrm{dl}$ mean corpuscular hemoglobin concentration, and $395 \times 10^{9} / 1(10.4 \%)$ reticulocyte count.

Red cell membrane proteins were fractionated on nonlinear gradient $3.5-17 \%$ polyacrylamide gels (10). Red cell membrane proteins were quantified by densitometry of Coomassie blue-stained gels at $540 \mathrm{~nm}$ using a Hoefer Scientific Instrument apparatus, model GS300 (San Francisco, CA, USA). The amount of spectrin was expressed as a ratio to band 3 and this ratio was $1.02 \pm 0.05$ in 30 normal controls. In fact, this ratio is obtained by dividing the area under the curve of the densitometric scan of spectrin by the area under the curve of the densitometric scan of band 3. As the area is approximately equal for both proteins, the normal ratio is about 1.00 .

Immunoblotting analysis was performed with proteins extracted from erythrocyte ghosts (11) and from intact red cells. The protein samples were run simultaneously in a BioRad minigel apparatus containing two $6 \%$ polyacrylamide-SDS gels. Electrotransfer of the proteins from one of the $6 \%$ polyacrylamide-SDS gels to nitrocellulose was carried out as described by Towbin et al. (12). The nitrocellulose blot was incubated with polyclonal anti-human $\beta$-spectrin antibodies for $20 \mathrm{~h}$ at $4^{\circ} \mathrm{C}$ and washed for $60 \mathrm{~min}$ with blocking buffer ( $3 \%$ nonfat dry milk, $10 \mathrm{mM}$ Tris, $150 \mathrm{mM} \mathrm{NaCl}$, and $0.02 \%$ Tween 20 ). The blot was subsequently incubated with $2 \mu \mathrm{Ci}$ of ${ }^{125}$ I-protein A in $10 \mathrm{ml}$ of blocking buffer for $1 \mathrm{~h}$ at $22^{\circ} \mathrm{C}$ and then washed for 2 h. The filter was exposed to Kodak X-Omat film with an intensifying screen at $-70^{\circ} \mathrm{C}$. The second gel was stained with Coomassie blue.
Leukocyte genomic DNA was extracted by standard techniques using phenol-chloroform. The 31 coding exons of the $\beta$-spectrin gene were amplified by PCR (13) using intronic primers. The amplified products were subsequently analyzed by non-radioactive SSCP in a PhastSystem apparatus (Pharmacia, Uppsala, Sweden).

The PCR products exhibiting abnormally migrating bands were directly sequenced using the Thermo Sequenase ${ }^{\mathrm{TM}}$ radiolabeled terminator cycle sequencing kit (Amersham, Cleveland, OH, USA). The amplification products presenting frameshift mutations were subcloned into pMOSblue vectors (Promega, Madison, WI, USA) and sequenced using the Thermo Sequenase ${ }^{\mathrm{TM}}$ cycle sequencing kit (Amersham).

Reticulocyte mRNA was extracted by the method of Kan et al. (14), reversetranscribed and amplified in a single-step reaction that included a $30-$ min cycle at $42^{\circ} \mathrm{C}$ followed by 40 cycles of a standard cycling PCR. The amplification products were digested with the restriction enzyme $D d e I$, that recognized a heterozygous N439S polymorphism in patient RS.

Densitometric scans of Coomassie bluestained SDS-PAGE of erythrocyte membrane proteins showed a $22 \%$ reduction in spectrin content (Figure 1). These findings indicate that mutations of the $\beta$-spectrin gene were likely to be responsible for the primary defect. The DNA amplification product of exon 20 showed an abnormal migration pattern when analyzed by SSCP in two independent experiments (Figure 2a). Sequencing of the cloned PCR products revealed, in both patients, a normal and a mutant clone, the latter bearing a $\mathrm{C}$ deletion at codon 1392 (Figure 2b).

Taking advantage of known polymorphisms, we next assessed the presence of the mutant mRNA transcripts in reticulocytes. The patient was heterozygous for an N439S polymorphism in exon 11, which affects a DdeI site. No loss of heterozygosity of the cDNA in relation to the genomic DNA could 
b)

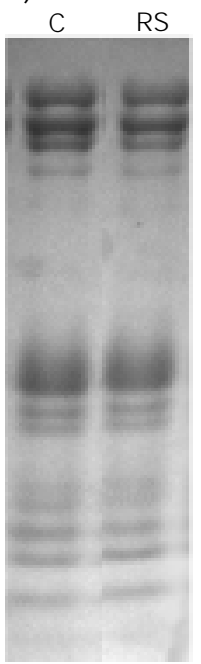

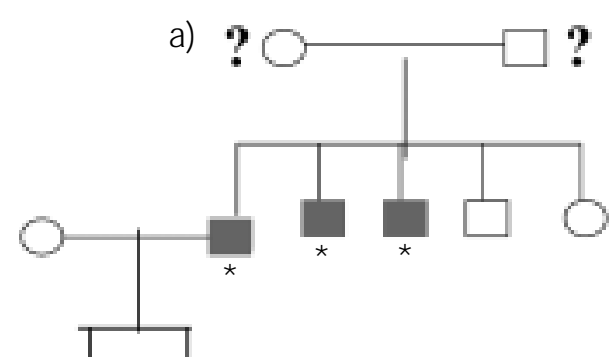

c)



Figure 1. a, Family pedigree showing affected members for three generations. Splenectomized individuals are indicated by an asterisk and the proband is indicated by an arrow. b, Exponential gradient (3.5 to 17\%) SDS-polyacrylamide gel of total membrane proteins stained with Coomassie blue, showing a reduction of spectrin content in the patient (RS) compared with the control (C). C, Blood smear from the propositus showing regular numbers of spherocytes and acanthocytes (arrows).

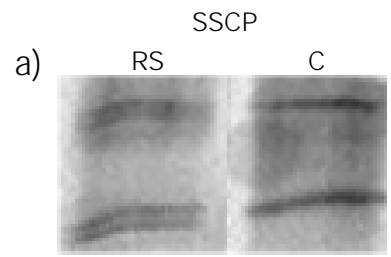

Exon 20

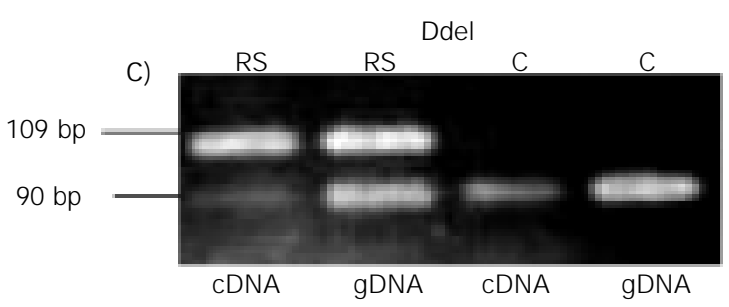

b)

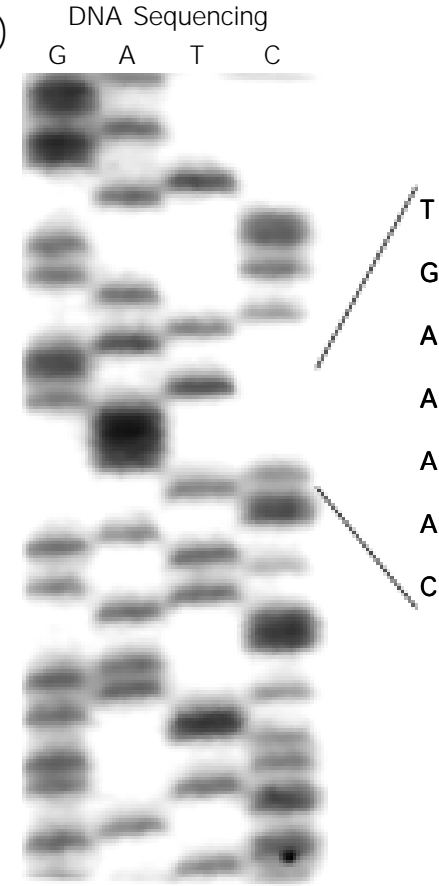

Exon 20
Figure 2. Analysis of ß-spectrin gene mutations. a, Non-radioactive SSCP showing a band shift in the amplification product of exon 20 of patient RS compared with control (C). b, Sequence analysis of a mutant clone originating from patient RS. The sequence in the region of the deletion is indicated and the deleted nucleotides appear on the right next to the position where they should be found. c, mRNA analysis. Digestion of exon 11 amplified products of patient RS with Ddel. Genomic DNA (gDNA), as well as CDNA reverse transcribed from reticulocyte mRNA, were used as templates for PCR as indicated. Note that the patient retained a heterozygous digestion pattem at the cDNA level. The control (C) is homozygous for N439S polymorphism in exon 11. 
be demonstrated (Figure 2c), indicating that the mutant mRNA transcripts are present at detectable levels. However, quantification analysis of the cDNA band ratio compared to the genomic DNA band ratio indicated a $73.4 \%$ reduction of mutant mRNA compared to its normal counterpart in patient RS, suggesting that the mutant mRNA is unstable. Frameshift mutations of the $\beta$-spectrin gene associated with spectrin deficiency have been previously reported and in all cases the mutant mRNA could not be detected $(6,7)$. This is the second report of a frameshift mutation of the $\beta$-spectrin gene associated with HS and spectrin deficiency, that presents a slightly stable mutant mRNA (15).

The $\mathrm{C}$ deletion at codon 1392 leads to premature termination after 19 amino acids, leading to truncated proteins. To verify the presence of this truncated protein in the membrane or in the cytoplasm of the red cells, we performed a Western blotting analysis of ghosts and intact cells using anti- $\beta$-spectrin antibodies. The truncated proteins were not detected in either fraction (data not shown), suggesting that the mutant proteins are rapidly degraded and that the mutation leads to a null phenotype, apparently common in $\beta$ spectrin-related dominant HS $(16,17)$.

The $\beta$-spectrin gene contains 31 exons. Frameshift mutations of the $\beta$-spectrin gene at the 3' end (exons 29, 30 and 31) allow the insertion of the mutant protein in the red cell membrane, leading to a defect in the autoassociation of the spectrin dimers and consequently to elliptocytosis $(1,2,18-20)$. On the other hand, the frameshift mutation in exon 20 observed in $\beta$-spectrin São Paulo ${ }^{\mathrm{II}}$ leads to an unstable mRNA, absence of the truncated protein of the red cell membrane and spectrin deficiency. This probably caused uncoupling of the lipid bilayer, spherocytosis and acanthocytosis.

\section{Acknowledgments}

We would like to thank Dr. Hani Hassoun for providing the primers used in this study and Dilmara L. Vicentim for technical support.

\section{References}

1. Lux SE \& Palek J (1995). Disorders of the red cell membrane. In: Handlin RI, Lux SE $\&$ Stossel TP (Editors), Blood Principles and Practice of Hematology. JB Lippincott, Philadelphia, PA, USA, 1701-1818.

2. Gallagher PG, Forget BG \& Lux SE (1998). Disorders of the enythrocyte membrane. In: Nathan DG \& Orkin SH (Editors), Hematology of Infancy and Childhood. 5th edn. Vol. 1. Saunders, Philadelphia, PA, USA, 544-664.

3. Tse WT \& Lux SE (1999). Red blood cell membrane disorders. British J ournal of Haematology, 104: 2-13.

4. Becker PS, Tse WT, Lux SE \& Forget BG (1993). ß-spectrin Kissimmee: a spectrin variant associated with autosomal dominant hereditary spherocytosis and defective binding to protein 4.1. J ournal of Clinical Investigation, 92: 612-616.

5. Hassoun $\mathrm{H}$, Vassiliadis J N, Murray J, Yi SJ , Hanspal M, Ware RE, Winter SS, Chiou S-S \& Palek J (1995). Molecular basis of spectrin deficiency in B spectrin
Durham. J oumal of Clinical Investigation, 96: 2623-2629.

6. Hassoun $\mathrm{H}$, Vassiliadis J N, Murray J, Yi SJ , Hanspal M, J ohnson CA \& Palek J (1996). Hereditary spherocytosis with spectrin deficiency due to an unstable truncated B spectrin. Blood, 87: 25382545.

7. Hassoun H, Vassiliadis J N, Murray J, Njolstad PR, Rogus J J , Ballas SK, Schaffer F, J arolim P, Brabec V \& Palek J (1997). Characterization of the underlying molecular defect in hereditary spherocytosis associated with spectrin deficiency. Blood, 90: 398-406.

8. Garbarz M, Galand C, Bibas D, Bournier O, Devaux I, HarousseauJ -L, Grandchamp B \& Dhermy D (1998). A 5' splice region $\mathrm{G} \rightarrow \mathrm{C}$ mutation in exon 3 of the human Bspectrin gene leads to decreased levels of $B$-spectrin mRNA and is responsible for dominant hereditary spherocytosis (spectrin Guemene-Penfao). British J ournal of Haematology, 100: 90-98.
9. Bassères DS, Vicentim DL, Costa FF, Saad STO \& Hassoun H (1998). ß-spectrin Promissão: A translation initiation codon mutation of the ß-spectrin gene (ATG $\rightarrow$ GTG) associated with hereditary spherocytosis and spectrin deficiency in a Brazilian family. Blood, 91: 368-369.

10. Fairbanks G, Steck TL \& Wallach DFH (1971). Electrophoretic analysis of the human erythrocyte membrane. Biochemistry, 10: 2606-2614.

11. Dodge JT, Mitchell C\& Hanahan DJ (1963). The preparation and chemical characteristics of hemoglobin-free ghosts of human erythrocytes. Archives of Biochemistry and Biophysics, 100: 119-130.

12. Towbin H, Staehelin J T \& Gordon J (1979). Electrophoretic transfer of proteins from polyacrylamide gels to nitrocellulose sheets: procedure and some applications. Proceedings of the National Academy of Sciences, USA, 76: 4350-4354.

13. Saiki RK, Geelfond DH, Stoffel S, Scharf SJ , Higuchi R, Hom GT, Mullis KB \& Erlich 
HÁ (1988). Primer-directed enzymatic amplification of DNA with a thermostable DNA polymerase. Science, 239: 487-491.

14. Kan YW, Holand J P, Dozy AM \& Varmus HE (1975). Demonstration of non-functional ß-globin mRNA in homozygous $ß^{0}$ thalassemia. Proceedings of the National Academy of Sciences, USA, 72: 51405144.

15. Bassères DS, Duarte ASS, Hassoun $H$, Costa FF \& Saad STO (2001). ß-spectrin Sta Barbara: a novel frameshift mutation in hereditary spherocytosis associated with detectable levels of mRNA and a germ cell line mosaicism. British J oumal of Haematology, 115: 347-353.

16. Dhermy D, Galand C, Boumier O, Cynober
T, Mechinaud F, Tchemia G \& Garbarz M (1998). Hereditary spherocytosis with spectrin deficiency related to null mutations of the ß-spectrin gene. Blood Cells, Molecules, and Diseases, 24: 251-261.

17. Miraglia del Giudice $E$, Lombardi C, Francese M, Nobili B, Conte ML, Amendola G, Cutillo S, Iolascon A \& Perrotta S (1998). Frequent de novo monoallelic expression of beta-spectrin gene (SPTB) in children with hereditary spherocytosis and isolated spectrin deficiency. British J oumal of Haematology, 101: 251-254.

18. Garbarz M, Tse WT, Gallagher PG, Picat C, Lecomte MC, Galibert E, Dhermy D \& Forget BG (1991). Spectrin Rouen ( $\beta^{220 / 218) ~ a ~}$ novel shortened ß-chain variant in a kin- dred with hereditary elliptocytosis: characterization of the molecular defect as exon skipping due to a splice site mutation. J oumal of Clinical Investigation, 88: 76-81.

19. Tse WT, Gallagher PG, Pothier B, Costa FF, Scarpa A, Delaunay J \& Forget BG (1991). An insertional frameshift mutation of the ß-spectrin gene associated with elliptocytosis in spectrin Nice (\$220/216). Blood, 78: 517-523.

20. Bassères DS, Pranke PHL, Sales TSI, Costa FF \& Saad STO (1997). ß-spectrin Campinas: a novel shortened ß-chain variant associated with skipping of exon 30 and hereditary elliptocytosis. British J ournal of Haematology, 97: 579-585. 